\title{
GOLDEN AGE SPAIN
}

\author{
HENRY KAMEN
}

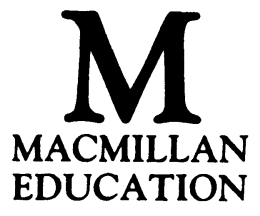


All rights reserved. No reproduction, copy or transmission of this publication may be made without written permission.

No paragraph of this publication may be reproduced, copied or transmitted save with written permission or in accordance with the provisions of the Copyright Act 1956 (as amended), or under the terms of any licence permitting limited copying issued by the Copyright Licensing Agency, 33-4 Alfred Place, London WC1E 7DP.

Any person who does any unauthorised act in relation to this publication may be liable to criminal prosecution and civil claims for damages.

First published 1988

Published by

MACMILLAN EDUCATION LTD

Houndmills, Basingstoke, Hampshire RG21 2XS

and London

Companies and representatives

throughout the world

Typeset by Wessex Typesetters

(Division of The Eastern Press Ltd.)

Frome, Somerset

British Library Cataloging in Publication Data

Kamen, Henry

Golden age Spain.-(Studies in European

history).

1. Spain, 1469-1714

I. Title II. Series

946

ISBN 978-0-333-41930-4 ISBN 978-1-349-08810-2 (eBook)

DOI 10.1007/978-1-349-08810-2 


\section{Contents}

Editor's Preface v

A Note on References vi

1 Introduction 1

2 Spain as a Great Power 5

3 The Peninsular Economy 19

4 Political Evolution 37

5 Society and Culture 51

6 Conclusion 61

Select Bibliography $\quad 65$

Glossary $\quad 77$

$\begin{array}{ll}\text { Index } & 79\end{array}$ 


\section{Editor's Preface}

The main purpose of this new series of Macmillan studies is to make available to teacher and student alike developments in a field of history that has become increasingly specialised with the sheer volume of new research and literature now produced. These studies are designed to present the 'state of the debate' on important themes and episodes in European history since the sixteenth century, presented in a clear and critical way by someone who is closely concerned himself with the debate in question.

The studies are not intended to be read as extended bibliographical essays, though each will contain a detailed guide to further reading which will lead students and the general reader quickly to key publications. Each book carries its own interpretation and conclusions, while locating the discussion firmly in the centre of the current issues as historians see them. It is intended that the series will introduce students to historical approaches which are in some cases very new and which, in the normal course of things, would take many years to filter down into the textbooks and school histories. I hope it will demonstrate some of the excitement historians, like scientists, feel as they work away in the vanguard of their subject.

The format of the series conforms closely with that of the companion volumes of studies in economic and social history which has already established a major reputation since its inception in 1968. Both series have an important contribution to make in publicising what it is that historians are doing and in making history more open and accessible. It is vital for history to communicate if it is to survive.

R. J. OVERY 


\section{A Note on References}

References are cited throughout in brackets according to the numbering in the general bibliography, with page references where necessary indicated by a colon after the bibliography number. 